\title{
UNINTENDED CONSEQUENCES: IT'S DISRUPTION OF WORK-LIFE BALANCE
}

\author{
Paul Stephens, Bradley University, prs@bradley.edu \\ Matthew McGowan, Bradley University, mmcgowan@bradley.edu \\ Charles Stoner, Bradley University, crs@bradley.edu \\ Jennifer Robin, Great Place to Work Institute, jrobin@greatplacetowork.com
}

\begin{abstract}
Advancements in information technology have provided many opportunities for people to stay connected both at work and in their personal lives. Researchers and the popular press have argued that such connectivity would bring increased flexibility to both the firm and the individual. For the firm, this flexibility was to lead to productivity gains, improve information transparency, and make it easier to meet and exceed the needs of customers. As for the individual employee, flexibility would improve worklife balance. The idea was that the individual could choose when and where to work, thus allowing one to mesh personal life and work life in a more harmonious way. What proponents did not fully explore was that such technological advancements would allow employers to create a new work culture that would use technology to make their employees do more, work longer hours and blur the boundaries between a person's work life and personal life. In this paper, we argue that this is exactly what has happened to many people. We collected data from approximately 100 working professionals. Our results suggest that in many cases, company expectations that their employees use connectivity technologies have done more to damage work-life balance than to help it.
\end{abstract}

Keywords: Work-life balance, Work extending technology, Information technology (IT), Flexible work

\section{INTRODUCTION}

Advances in information and computing technologies have made it possible for work to be done outside of traditional working hours and away from traditional work locations [9]. Computer technologies were once confined to the office; when one left the office, it was no longer possible to perform work that required access to the computer. Before cell phones, it was generally necessary to phone a worker at an office phone, and perhaps find a worker at his desk or hope that a co-worker would answer and write a message on a piece of paper. Now messages can be left on voice mail or workers can be contacted at their cell phones. Computers were adopted by technologists and hobbyists for home use, but are now a part of daily life at home for most of our society [11]. Equipped with technologies such as cell phones, personal digital assistants (PDAs), e-mail, laptop computers, fax capabilities, voice mail, and a myriad of other technologies workers can stay connected to work 24/7. Towers et al. [9] describe these technologies as work extending technologies. Workers can continue to be productive when they travel or when they go home. Recently, researchers have questioned how technology has impacted people's lives at work and at home.

A survey conducted by the Association of Executive Search Consultants found that of the 1311 senior executives surveyed, $46 \%$ report that the quality of their work-life balance has gotten worse in the past five years and 59\% report having less leisure time in their lives since the onset of connectivity technologies. It does not take much imagination to infer a connection between these two things. But, the survey merely implies a connection and the relationship has not been statistically validated. Manny Avramidis, senior vice-president of global human resources at American Management Association has noticed that "people are increasingly worried that technology is creeping into their personal space.” [8]

Companies have used a variety of work arrangements to allow their employees to perform work away from the traditional workplace. One type of work arrangement involves telecommuting, an arrangement in which an employee works from home most of the time and uses telecommunications and computers to work during normal business hours [5]. Telecommuting typically involves an explicit understanding between the company and the employee regarding what work will be done. Other researchers have classified this alternative as flexible work arrangements [7] or flexible work options [6]. While there are important issues in establishing these telecommuting arrangements, companies are actively involved in making them. Whereas, in other 
situations where technology is involved work arrangements are not actively managed.

Duxbury et al. [5] used the phrase after-hours telecommuting to refer to situations in which employees do supplemental work away from the office outside of regular working hours. Work arrangements for this type of extended work are more often the result of implicit understandings or company culture rather than normal work arrangements. Employees may feel that companies who equip them with technologies that permit them to work away from the office are expecting the employees to use them away from the office.

Researchers have suggested that work extending technologies have the potential to increase autonomy, flexibility, control, and convenience [5]. Work extending technologies make the boundaries between work and home more permeable, overlapping these activities in space, time, and across psychological borders.. [10]. It is not clear whether these impacts are more positive or negative.

Extending technologies can be used to bring work home, but can also be used to bring home to work, phenomena identified as spillover [2]. A mother might be instant messaging with her college student as she performs work activities while at her place of employment. She might also receive an e-mail note from her high school student. These activities allow her to stay connected to family without disrupting her work. A father may be on the phone to a client while watching his child play soccer. Or he could use his laptop to prepare a report for work while he is sitting in the living room with the rest of his family. These types of activities have been identified as spillover; when work spills over to home or home spills over to work $[2,9]$.

Spillover can occur in both directions and can be positive or negative. Perhaps the mother ignored a coworker's request while instant messaging, and the father missed seeing his child score a goal while engaged in his phone conversation. Chesley [2] found that communications (cell phone and pager) is linked to increases in negative work-to-family spillover and family-to-work spillover, but found no link between computer communications (e-mail and Internet) and spillover.

When spillover occurs predominantly in one direction, it can lead to an imbalance between one's work role and family role. When there is too much work spilling over to home, it can result in work overload. Companies may tolerate spillover from home to work as long as it does not adversely affect one's job performance. But companies do not seem to be concerned about work extending too far into the home, and some corporate cultures expect employees to take work home $[9,10]$. The impact of work spilling over into home can not simply be quantified and measured as the number of hours an employee works at home. Instead, one must examine the influence in terms of the perceived impact on worklife satisfaction. For example, Duxbury and Higgins [4] (c.f. Towers et al.[9]) found that 70 percent of the workers in their study reported that using work extending technologies had increased their workloads and stress levels, but 65 percent reported found that it made their jobs more interesting.

Researchers have used a variety of phrases to describe the relationship of work and non-work activities. Byrne [1] adopts the phrasing of The Work Foundation, that "balance is about people having a measure of control over when, where, and how they work." (p. 56) Illingsworth [6] uses the phrase "work-life blending." Towers et al. [9] uses "work/family boundaries" when discussing family issues, and "work/life boundaries" to discuss other situations. Valcour and Hunter [10] use "work-life integration" to discuss the multiple demands of work and non-work domains. While researchers generally agree that there are many aspects to this concept that cannot be properly captured in one phrase, we use the term life-balance because of its prevalence in the literature. The idea of balance connotes a static state, and researchers agree that work-life balance may not be a static state for most of us.

Valcour \& Hunter [10] propose a multifaceted model of technology's impact on work-life balance. Their model suggests that there may be mediating factors that influence the effects of technology such as organizational culture, human resource practices, managers, and various individual characteristics, and these variables together influence perceptions of work-life balance. We examine the link between technology and work-life balance considering mediating factors organizational work culture, distribution of jobs, and redistribution of work across time and space. Our model (adapted from Valcour and Hunter) of the effects of technology on work-life balance is illustrated in Figure 1. 


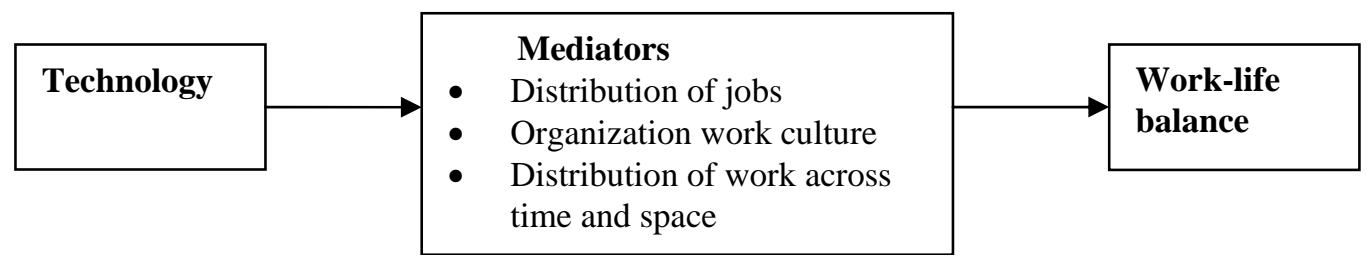

Figure 1. Model of the effects of technology on work-life balance.

Very little empirical research has looked at the relationship between the use of work extending technologies and work-life balance $[2,10]$. DeBruin and Dupuis [3] suggest that further research is needed to conceptualize the notion of work-life balance, and to see how different types of workers react to work extending technologies. This research examines how various technologies relate to perceived flexibility and autonomy for employees. We examine how the use of these technologies influence when one works, where one works, and what work one does.

\section{METHODOLOGY AND RESULTS}

A survey instrument was used to capture data from a pool of working professionals. Ninety six usable surveys were returned. The respondents were specifically asked about the required use of connectivity technologies by their employers. Table 1 illustrates the distribution over the various connectivity technologies.

Table 1. \% of Respondents who are expected to use connectivity technology.

\begin{tabular}{|l|l|}
\hline Connectivity Technology & $\begin{array}{l}\text { Employer } \\
\text { Expects Use }\end{array}$ \\
\hline Electronic Mail & $84 \%$ \\
\hline Voice Mail & $83 \%$ \\
\hline Computer Organizational & $79 \%$ \\
\hline Access to Organizational Files & $76 \%$ \\
\hline Fax to & $75 \%$ \\
\hline $\begin{array}{l}\text { Access } \\
\text { Information Systems }\end{array}$ & $61 \%$ \\
\hline Cell Phone & $49 \%$ \\
\hline Teleconferencing & $21 \%$ \\
\hline Web Conferencing & $13 \%$ \\
\hline Instant Messaging & $10 \%$ \\
\hline Video Conferencing & $7 \%$ \\
\hline PDA & $6 \%$ \\
\hline Groupware & $2 \%$ \\
\hline Pager &
\end{tabular}

The purpose of this research is to examine the effect of connectivity technologies on an individual's ability to work when and where they want (flexibility), what they work on (autonomy) and whether the employer requires the use of such technologies to improve the employee's work-life balance. Respondents were initially split into two groups; low expected use and high expected use of connectivity technology. To establish the two groups we counted how many respondents were required to use the various number of connectivity technologies (See table 2).

Table 2. How many of these technologies are you required to use?

\begin{tabular}{|l|l|}
\hline $\begin{array}{r}\text { of } \\
\text { Technologies }\end{array}$ & Count \\
\hline 0 & 7 \\
1 & 2 \\
2 & 4 \\
3 & 4 \\
4 & 5 \\
5 & 3 \\
6 & 11 \\
7 & 21 \\
8 & 20 \\
9 & 10 \\
10 & 8 \\
11 & 1 \\
\hline
\end{tabular}

As you can see, seven respondents aren't required to use any connectivity technology. The mode of the group is seven technologies and that is where we decided to split our two groups ( 6 and below $(n=36)$ vs. 7 and higher $(\mathrm{n}=60)$ ). A simple ANOVA is used to compare the two groups versus two separate measures of flexibility (when and where work is performed), one measure of autonomy (what work is performed) and one measure of employer intentions (see tables 3 and 4). 
Table 3. Respondent questions on a 1 to 5 Scale.

\begin{tabular}{|l|l|l|l|}
\hline Category & Question & From 1 & To 5 \\
\hline Flexibility & $\begin{array}{l}\text { How much flexibility do you have in selecting the } \\
\text { location of where you work? (A) }\end{array}$ & None & Complete \\
\hline Flexibility & $\begin{array}{l}\text { How much flexibility do you have in scheduling when } \\
\text { you do your work? (B) }\end{array}$ & None & Complete \\
\hline Autonomy & $\begin{array}{l}\text { How much flexibility do you have in scheduling what } \\
\text { work you will do? (C) }\end{array}$ & None & Complete \\
\hline $\begin{array}{l}\text { Employer } \\
\text { Intentions }\end{array}$ & $\begin{array}{l}\text { My company supports connectivity because it makes life } \\
\text { balance more manageable for employees. (D) }\end{array}$ & $\begin{array}{l}\text { Strongly } \\
\text { Disagree }\end{array}$ & $\begin{array}{l}\text { Strongly } \\
\text { Agree }\end{array}$ \\
\hline
\end{tabular}

Table 4. Results of ANOVA analysis.

\begin{tabular}{|l|l|l|l|}
\hline & \multicolumn{2}{|l|}{$\begin{array}{l}\text { Required Connectivity } \\
\text { Technology Usage }\end{array}$} & \\
\hline Question & $\begin{array}{l}\text { Low } \\
(\mathbf{n = 3 6 )}\end{array}$ & High (n=60) & Significance \\
\hline A & 2.64 & 2.22 & .147 \\
\hline B & 3.14 & 2.68 & .066 \\
\hline C & 3.35 & 3.28 & .791 \\
\hline D & 3.58 & 3.07 & .026 \\
\hline
\end{tabular}

There appears to be no statistically significant difference between the two groups in terms of the flexibility and autonomy that one might expect from connectivity technologies. Additionally, respondents who are required to use connectivity technologies are more likely to disagree that their employers provide such technology to make work-life balance for their employers more manageable.

As we pondered these results, we argued that certain connectivity technologies might be time and place constrained and not truly portable. It is possible that many of the connectivity technologies would require the employee to be at the work site. For example, something as seemingly flexible as e-mail may require the employee to be at work in order to read work related communications. Work related e-mail and file servers, work related information systems such as databases and ordering systems may require VPN (virtual private network) support in order for employees to use such systems away from the work site. On the other hand, some of the technologies appear to be clearly portable such as a cell phone, pager or PDA. It would seem that portability would be necessary in order for flexibility to occur.

To further explore this possibility, we partitioned the connectivity technologies into two groups: (1) almost always portable and (2) may be required to be at work. Table 5 illustrates the division along with the percentage of required use reported by the respondents.
Table 5. Clearly Portable versus Not Necessarily Portable Connectivity Technologies.

\begin{tabular}{|l|l|l|l|}
\hline $\begin{array}{l}\text { Almost } \\
\text { Always } \\
\text { Portable }\end{array}$ & $\begin{array}{l}\text { Employer } \\
\text { Requires } \\
\text { Use }\end{array}$ & $\begin{array}{l}\text { May } \\
\text { Required to be } \\
\text { at Work }\end{array}$ & $\begin{array}{l}\text { Employer } \\
\text { Requires } \\
\text { Use }\end{array}$ \\
\hline $\begin{array}{l}\text { Cell } \\
\text { Phone }\end{array}$ & $61 \%$ & Electronic Mail & $84 \%$ \\
\hline PDA & $7 \%$ & Voice Mail & $83 \%$ \\
\hline Pager & $2 \%$ & Computer & $79 \%$ \\
\hline & & Access to Files & $76 \%$ \\
\hline & & Fax & $75 \%$ \\
\hline & $\begin{array}{l}\text { Access to Info } \\
\text { Systems }\end{array}$ & $66 \%$ \\
\hline & Teleconferencing & $49 \%$ \\
\hline & $\begin{array}{l}\text { Web } \\
\text { Conferencing }\end{array}$ & $21 \%$ \\
\hline & $\begin{array}{l}\text { Instant } \\
\text { Messaging }\end{array}$ & $13 \%$ \\
\hline & $\begin{array}{l}\text { Video } \\
\text { Conferencing }\end{array}$ & $10 \%$ \\
\hline & & Groupware & $6 \%$ \\
\hline & & & \\
\hline & & &
\end{tabular}

The reader will notice that the top six required technologies all fall into the second category. What we decided to do next was to run an ANOVA analysis between the second category and our measures of flexibility, autonomy and perceived employer intentions. We then repeated this for the first category (see tables 6 and 7).

Table 6. Results of ANOVA analysis - May be Required to be at Work.

\begin{tabular}{|l|l|l|l|}
\hline & \multicolumn{2}{|l|}{$\begin{array}{l}\text { Required Connectivity } \\
\text { Technology Usage }\end{array}$} & \\
\hline Question & $\begin{array}{l}\text { Low } \\
(\mathbf{n = 3 6 )}\end{array}$ & High (n=60) & Significance \\
\hline A & 3.20 & 2.22 & .011 \\
\hline B & 3.47 & 2.74 & .028 \\
\hline C & 3.29 & 3.32 & .906 \\
\hline D & 3.79 & 3.04 & .002 \\
\hline
\end{tabular}


Table 7. Results of ANOVA analysis - Almost Always Portable.

\begin{tabular}{|l|l|l|l|}
\hline & \multicolumn{2}{|l|}{$\begin{array}{l}\text { Required Connectivity } \\
\text { Technology Usage }\end{array}$} & \\
\hline Question & $\begin{array}{l}\text { Low } \\
(\mathbf{n}=\mathbf{3 6})\end{array}$ & High (n=60) & Significance \\
\hline A & 2.31 & 2.42 & .704 \\
\hline B & 3.03 & 2.75 & .266 \\
\hline C & 3.43 & 3.23 & .412 \\
\hline D & 3.31 & 3.24 & .772 \\
\hline
\end{tabular}

The results are insightful. Those respondents who report a low required use of connectivity technology report a higher degree of flexibility in choosing when and where they work. Clearly, the required use of connectivity technology in many cases leads to reduced flexibility. Additionally, connectivity technologies that are most portable have no impact on flexibility.

It appears that all connectivity technologies have little direct impact on autonomy in the workplace. Employees' work requirements are determined by the design of their jobs and directions from their supervisors. Work extending technology plays no role in deciding what work needs to be done.

What is very interesting is the respondent perception of why their employers required them to use connectivity technologies. Specifically, we wanted to know if the employees felt that employers were using such technologies to help them improve their work-life balance. What we find is that those who are required to use those technologies that are more likely to be time and place constrained are more likely to disagree that their employer is requiring these technologies in order to improve their work-life balance. It appears the patterns start to change when we look at the truly portable technologies, but there are still no statistically significant differences between those required to use the technology and those who are not required to use it.

On the other hand, when we ask respondents if employers are using such technologies to create advantages for the employers, the respondents overwhelmingly agree. Eighty-seven percent of the respondents agree or strongly agree that the company supports connectivity technology because it allows the company to better meet the needs of its customers and eighty-four percent of the respondents agree or strongly agree that the company supports the use of such technology because it promotes greater productivity at work.

\section{DISCUSSION AND CONCLUSIONS}

The literature is mixed regarding the advantages and disadvantages of connectivity technologies used in the workplace. Some people have envisioned a future where technology frees us to lead more balanced lives while others point to a reality where technology is being used to make employees work harder and longer. Do such technologies make us slaves to our work or do they provide us with the flexibility necessary to maintain a positive balance between our working lives and personal lives?

Our research indicates that connectivity technology is currently making some lives less flexible and making it harder to maintain work-life balance. Our findings indicate that perhaps we haven't reached the point where such technologies are truly portable and thus inherently time and place constrained. What is encouraging is that such technologies continue to improve over time and seem to be moving us to an ever more portable working society.

Employers are using connectivity technologies to their advantage and their employees recognize this. These same employees believe that their employers do not intend to use these technologies to help them balance their work and personal lives. The majority of the technologies are time and place constrained and the employer is not looking for ways to use this technology to improve balance. Therefore, it has become more difficult for the individual to achieve balance.

\section{Noted Weaknesses of this Research}

A weakness of our data is that the majority of the respondents work in industries in which work is more likely to be location and time constrained: Manufacturing, Education, Health Care and Retail [10]. We recommend that further studies explore industries and jobs where the portability of the majority of connectivity technologies discussed in this article are common.

We must also recognize that the number of respondents in our study is low. One must question the power of any conclusion reached via this research. Further research would benefit from a revised questionnaire and a larger sample. Furthermore, such research should capture how often employees are using connectivity technology and the extent to which this use carries over into their personal lives. 


\section{Future Research}

A comprehensive model that explains the link between connectivity technology, work-life balance, job satisfaction and life satisfaction has never been extrapolated. The model provided by Valcour and Hunter [10] gives us some insights into the links between technology and balance but hasn't been empirically verified. The next step in the process should be to further refine this model, expand upon the model and empirically test the model. This study focused on upwardly mobile managers and professionals. The model should also be tested on a broader range of knowledge workers. There may be characteristics of managers and professionals that lead them to different usage patterns than other knowledge workers.

Current research has focused on the relationship between technology and work life balance. But, little has been written to suggest how this relationship can be optimized to create a win-win environment for both employers and employees. Once we understand the dynamics of the relationship, future research can focus on specific policies that companies can follow. Additionally, we should be able to identify specific behaviors that individuals (both managers and subordinates) must institute in order to get the most out of the work extending technologies of the present and future. As an added benefit, such work will provide us with insight as to how technology should change in order to support balance.

This study has shown that the use of work extending technologies may not improve the work-life balance of employees. There are ethical issues that arise if employers are providing these technologies to extend the work days of their employers. The motives of employers in supplying work extending technologies should be examined further.

\section{REFERENCES}

1. Byrne, Una. (2005) Work-life balance: Why are we talking about it all? Business Information Review, 22:1, pp. 53-59.

2. Chesley, Noelle. (2005) Blurring boundaries? Linking technology use, spillover, individual distress, and family satisfaction. Journal of Marriage \& Family, 67:5 (December), pp. 12371248.

3. De Bruin, Anne \& Dupuis, Ann. (2004) WorkLife Balance? Insights from non-standard work.
New Zealand Journal of Employment Relations, 29:1, pp. 21-37.

4. Duxbury, Linda Elizabeth, and Higgins, Christopher Alan. (2001) The 2001 National Work-Life Conflict Study: Report One, Health Canada, Ottawa.

5. Duxbury, Linda Elizabeth, Higgins, Christopher Alan, and Mills, Shirley. (1992) After-hours telecommuting and work-family conflict: A comparative Analysis. Information Systems Research, 3:2, pp. 173-190.

6. Illingsworth, Bob. (2004) Trust and technology: Work-life blending at Unisys. Strategic $H R$ Review, 4:1 (Nov/Dec), pp. 8-9.

7. Robinson, Will. (2005) Ethical considerations in flexible work arrangements. Business and Society Review, 110:2, pp. 213-224.

8. Silva, C. (2006), "Work-life concerns impede senior executive promotions", Employee Benefit News, October, p24.

9. Towers, Ian, Duxbury, Linda, Higgins, Christopher, \& Thomas, John. (2006) Time thieves and space invaders: technology, work, and the organization. Journal of Organizational Change, 19:5, pp. 593-618.

10. Valcour, P. M., \& Hunter, L. W. (2005). Technology, organizations, and work-life integration. In E. E. Kossek \& S. J. Lambert (Eds.), Managing work-life integration in organizations: Future directions for research and practice (pp. 61-84). Mahwah, NJ: Erlbaum.

11. Watt, David, and White, James M. (1999) Computers and the family life: A family development perspective. Journal of Comparative Family Studies, 30:1 (Winter), pp. 1-15. 